\title{
アルミニウムダイ鋳物にあらわれる ハードスポツトとその防止対策*
}

\section{大日方一司** \\ HARD SPOT IN LIGHT DIE-CASTING ALLOYS ITS CAUSES AND REMEDIES*}

ICHIJI OBINATA**

There are two sorts of hard spot which appears in the products of die-casting, one is of metallic and the other of non-metallic nature. The former is chiefly of primary crystals of various intermetallic compounds containing iron and manganese, as shown in Table. 1 and Photo. 1,a h.

The latter or hard spot of non-metallic nature has also been detected in some products of diecasting (Photo. 4 Photo. 8), as the causes of which the reaction products between the material of crucible or fire-clays and the molten alloy as well as the slag itself contained in the crude silicon have been pointed out.

Some remedies according as the causes of hard spot have been suggested.

(Received Feb. 7, 1956)

\section{1. 緒言}

ダイ鋳物にあらわれるハードスポツトについては、そ の発生原因の一部は既に本誌1 に発表した。当時のわが 国の鋳物業者は再生塊を主体とする不純物の多い原料を 使用する習慣があつたために、ハードスポツトは主とし て鉄を含む金属間化合物が主体であつた。その後、この 種ハードスポツトがクレイムの大きな原因となる事が認 識されるに至つたので、各業者は使用地金を吟味し、次 第に良質の合金を使用するようになつて来た。それにも かかわらず未だハードスポットの問題が全面的に解決さ れたとはいえない状態にある。例えば昨春開催されたダ イ鋳物委員会と本邦写真機製造業者との懇談会の席上で も、依然としてハードスポットの問題が写真機の生産性 を妨げている事実を再認識し、不良品の提出を求めてこ れが検討を行う事となつた。筆者はたまたまこれ等の試 料を調べる機会に恵まれたので、その調查の結果を報告 すると共に広くハードスポットの種類、発生原因、組成 等をのべこれが防止対策を提示しようと考える。

結論的にいえば、ハードスポットの種類としては、(1) 金属的なものと (2)非金属的なものの 2 種に大別し得る。 金属的なハードスポツトは主として合金の組成に注意す れば避けられるが、非金属的なハードスポツトは原料中 の洷、その他炉材との反応等主として熔解の方法に注意 しなければならない。
なおハードスポツトの定義であるが、この問題は鋳物 の切削加工と密接な関係をもち、仕上げの精度の高い場 合程、微粒のものでも問題となる。従つてどの程度の大 きさから問題となるかは一概にはいえないが、ここでは 仮に球状或は粒状の場合には $0.1 \mathrm{~mm}$ 、板状或いは片状 の場合には $0.3 \mathrm{~mm}$ 程度以上のもので、硬さはモース硬 度で 6 〜 程度以上、ミクロヴィツカース硬度で 300〜 500 程度以上のものと考えて置く。

\section{2. 金属的ハードスポツト}

金属的ハードスポツトの種類、発生原因、組成等につ いては既に本誌12号1)に詳細報告した。それ等の結果を 総括してみると Table.1 のようになる。

Photo. 1. a〜h には Table. 1 に示した各種の硬い金 属間化合物の実物写真を示す。これ等の試料はそれぞれ の金属間化合物が初晶出するような組成の合金を作り、 これを 1 昼夜位かけて徐冷した後、合金を塩酸溶液中で 電解して抽出したものである2)。いずれの化合物も表示 のように極めて硬いので、これ等の化合物が熔湯中に晶 出発達する場合には、当然鋳物中に混入して、いわゆる ハードスポツトとなり得るわけである。

Table. 2 には、本邦ダイ鋳物用アルミニウム合金の JIS 規格案を示した。表から明かに、ダイカスト用アル ミニウム合金としては、第 5 種および第 6 種の $\mathrm{Al}-\mathrm{Mg}$ 系 のものを除き他は凡て $\mathrm{Al}-\mathrm{Si}$ 系を主体とする。すなわ

\footnotetext{
* 軽金属研究会第 9 回秋期大会 (1955) 講演 ** 東北大学教授 ** Tohoku Univ.
} 
Table. 1 Metallic Hard Constituents Which may Appear in the Aluminium Alloy Systems.

\begin{tabular}{|c|c|c|c|c|c|c|}
\hline \multirow{2}{*}{$\begin{array}{l}\text { Alloy } \\
\text { system }\end{array}$} & \multicolumn{5}{|c|}{ Metallic hard constituent } & \multirow{2}{*}{$\begin{array}{l}\text { Composition limit } \\
\text { of primary } \\
\text { crystallization }\end{array}$} \\
\hline & $\begin{array}{l}\text { Sorts or } \\
\text { notation }\end{array}$ & $\begin{array}{l}\text { Molecular } \\
\quad \text { formula }\end{array}$ & $\begin{array}{c}\text { Hardness } \\
\text { VHN }\end{array}$ & $\begin{array}{c}\text { Specific } \\
\text { gravity }\end{array}$ & $\begin{array}{l}\text { Melting } \\
\text { point }\end{array}$ & \\
\hline $\mathrm{Al}-\mathrm{Fe}$ & $\mathrm{FeAl}_{3}$ or $\theta$ & $\mathrm{FeAl}_{3}$ & 960 & 3.81 & 1,158 & $\mathrm{Fe}>1.7 \%$ \\
\hline $\mathrm{Al}-\mathrm{Mn}$ & $\mathrm{Al}_{6} \mathrm{Mn}$ & $\mathrm{Al}_{6} \mathrm{Mn}$ & 540 & 3.09 & $710(P)$ & $\mathrm{Mn}>1.95 \%$ \\
\hline $\mathrm{Al}-\mathrm{Si}$ & $\mathrm{Si}$ & $\mathrm{Si}$ & 1,320 & $2.4 *$ & 1,410 & $\mathrm{Si}>11.7 \%$ \\
\hline $\mathrm{Al}-\mathrm{Si}-\mathrm{Fe}$ & $\alpha(\mathrm{FeSi})$ ork $_{5}$ & $\mathrm{Al}_{8} \mathrm{Fe}_{2} \mathrm{Si}$ & - & 3. $71 *$ & - & $\mathrm{Fe}>1.5 \%, \mathrm{Si}>4 \%$ \\
\hline " & $\beta(\mathrm{FeSi})$ or $\mathrm{K}_{6}$ & $\mathrm{Al}_{4} \mathrm{FeSi}$ & 578 & 3. $31 *$ & - & $\mathrm{Fe}>0.8 \%, \quad \mathrm{Si}>7.5 \%$ \\
\hline " & $\gamma(\mathrm{FeSi})$ or $\mathrm{K}_{4}$ & $\mathrm{Al}_{4} \mathrm{FeSi}_{2}$ & - & 3.78 & - & $\mathrm{Fe}>1.7 \%, \mathrm{Si}>1.4 \%$ \\
\hline $\mathrm{Al}-\mathrm{Fe}-\mathrm{Mn}$ & $\left(\mathrm{FeAl}_{3}-\mathrm{Mn}\right)$ & - & - & - & - & $\mathrm{Fe}>1.5 \%$ \\
\hline " & $\left(\mathrm{Al}_{6} \mathrm{Mn}-\mathrm{Fe}\right)$ & - & $514 *$ & 3.09 & - & $\mathrm{Mn}>0.75 \%$ \\
\hline $\mathrm{Al}-\mathrm{Si}-\mathrm{Mn}$ & $\alpha(\mathrm{MnSi})$ or $\mathrm{W}$ & $\mathrm{Al}_{10} \mathrm{Mn}_{2} \mathrm{Si}$ & 958 & 3. $68 *$ & - & $\mathrm{Si}>2 \%, \mathrm{Mn}>1.2 \%$ \\
\hline $\mathrm{Al}-\mathrm{Si}-\mathrm{Fe}-\mathrm{Mn}$ & $\alpha($ Fe Si Mn $)$ & $\mathrm{Al}_{9} \mathrm{MnFeSi}$ & - & 3. $77 *$ & - & $\mathrm{Fe}+\mathrm{Mn}>2 \%$ \\
\hline
\end{tabular}

* Measured by the present writer

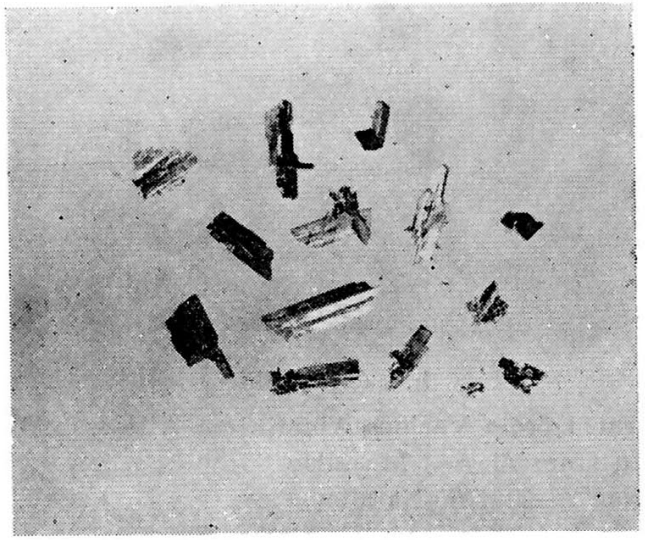

a. $\mathrm{FeAl}_{3}$

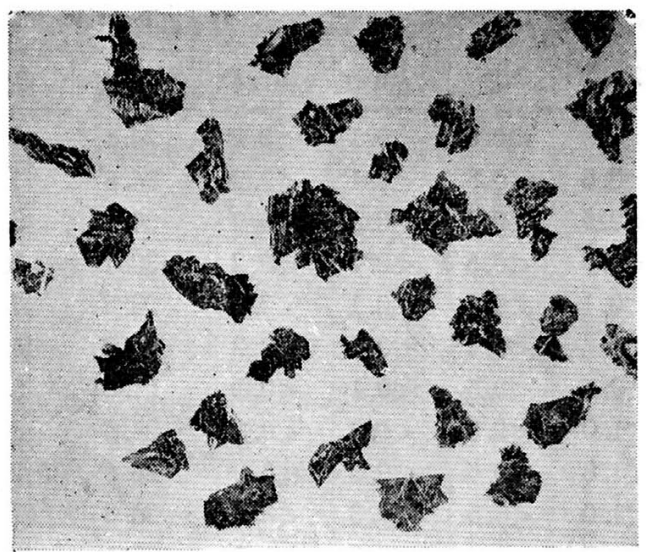

c. $\mathrm{Si}$

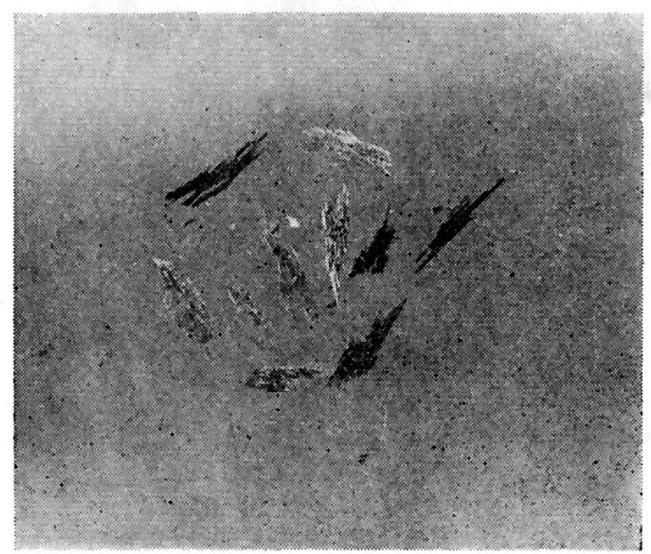

b. $\mathrm{Al}_{6} \mathrm{Mn}$

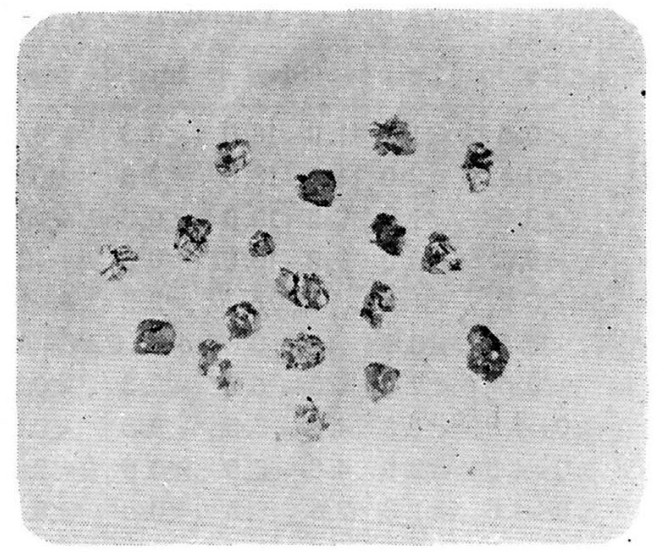

d. $\mathrm{Si}(\mathrm{Na})$ 

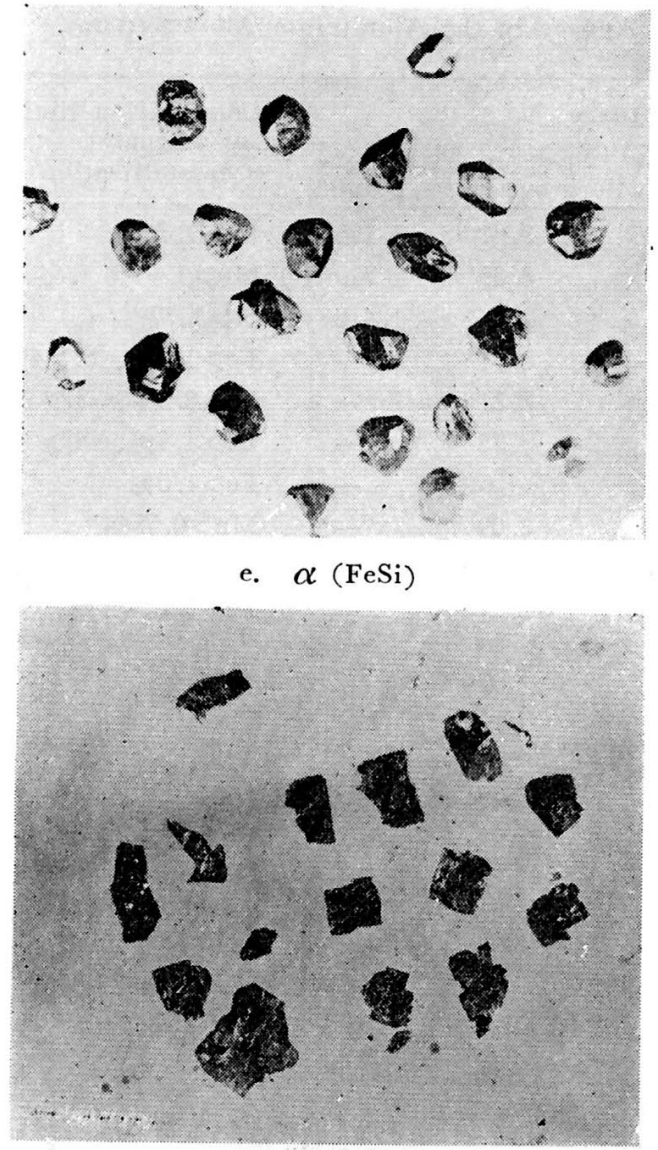

g. $\alpha(\mathrm{MnSi})$

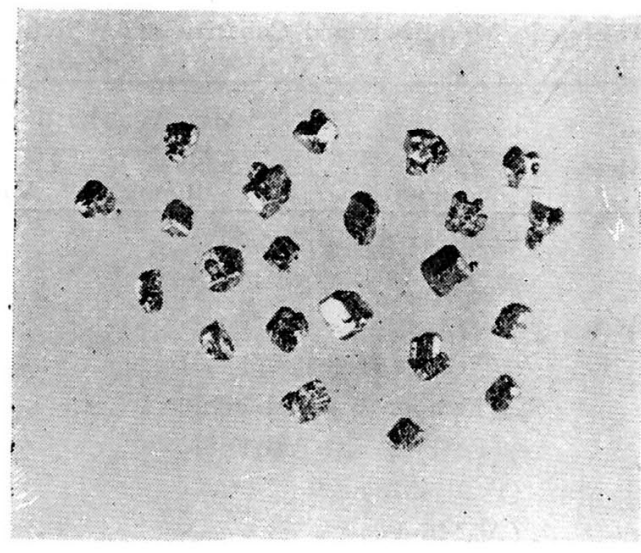

f. $\beta(\mathrm{FeSi})$

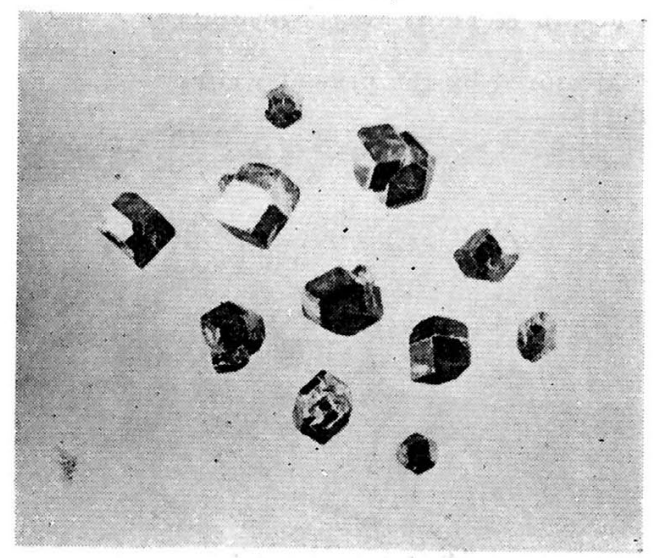

h. (MnFeSi)

Photo. 1 Primary Crystal's of Hard Constituents Separated from Various Aluminium Alloys. $\times 3$
a. $\mathrm{FeAl}_{3}$ from $\mathrm{Al}-20 \% \mathrm{Fe}$ alloy
b. $\mathrm{Al}_{6} \mathrm{Mn}$ from $\mathrm{Al}-4 \% \mathrm{Mn}$ alloy
c. Si from $\mathrm{Al}-20 \% \mathrm{Si}$ alloy
d. Si from $\mathrm{Al}-20 \% \mathrm{Si}-\mathrm{Na}$ alloy

e. $\alpha(\mathrm{FeSi})$ from $\mathrm{Al}-6 \% \mathrm{Fe}-10 \% \mathrm{Si}$ allo

f. $\beta(\mathrm{FeSi})$ from $\mathrm{Al}-5 \% \mathrm{Fe}-13 \% \mathrm{Si}$ alloy

g. $\alpha(\mathrm{MnSi})$ from $\mathrm{Al}-2 \% \mathrm{Mn}-8 \% \mathrm{Si}$ alloy

h. $(\mathrm{MnFeSi})$ from $\mathrm{Al}-2 \% \mathrm{Mn}-2 \% \mathrm{Fe}-\mathrm{Si}$ alloy

Table. 2 Aluminium Alloys for Die-casting (JIS-1955, Pending)

\begin{tabular}{|c|c|c|c|c|c|c|c|c|c|c|c|}
\hline \multirow{2}{*}{$\begin{array}{c}\text { Sorts of } \\
\text { alloys }\end{array}$} & \multicolumn{9}{|c|}{ Chemical } & \multicolumn{2}{|c|}{ Tensile test } \\
\hline & $\mathrm{Cu}$ & $\mathrm{Fe}$ & $\mathrm{Si}$ & Mn & $\mathrm{Mg}$ & $\mathrm{Zn}$ & $\mathrm{Ni}$ & $\mathrm{Sn}$ & others & $\begin{array}{c}\sigma_{B} \\
\mathrm{~kg} / \mathrm{mm}^{2}\end{array} \mid$ & $\delta \%$ \\
\hline 1 & $<0.6$ & $<1.3$ & $11.0 \sim 13.0$ & $<0.3$ & $<0.1$ & $<0.5$ & $<0.5$ & $<0.1$ & $<0.2$ & 24.5 & 3.5 \\
\hline 2 & $<0.6$ & $<2.0$ & $11.0 \sim 13.0$ & $<0.3$ & $<0.1$ & $<0.5$ & $<0.5$ & $<0.1$ & $<0.2$ & 26.0 & 1.8 \\
\hline 3 & $<0.6$ & $<1.3$ & $9.0 \sim 10.0$ & $<0.3$ & $0.4 \sim 0.6$ & $<0.5$ & $<0.5$ & $<0.1$ & $<0.2$ & 30.1 & 5.0 \\
\hline 4 & $<0.6$ & $<2.0$ & $9.0 \sim 10.0$ & $<0.3$ & $0.4 \sim 0.6$ & $<0.5$ & $<0.5$ & $<0.1$ & $<0.2$ & 30.1 & 3.0 \\
\hline 5 & $<0.2$ & $<1.8$ & $<0.3$ & $<0.3$ & $4 \sim 11$ & $<0.1$ & $<0.1$ & $<0.1$ & $<0.2$ & 28.8 & 7.5 \\
\hline 6 & $<0.12$ & $<0.8$ & $<1.3$ & $0.4 \sim 0.5$ & $2.5 \sim 4.0$ & $<0.4$ & $<0.1$ & $<0.1$ & $<0.2$ & 28.8 & 10.0 \\
\hline 7 & $<0.6$ & $<2.0$ & $4.5 \sim 6.0$ & $<0.3$ & $<0.1$ & $<0.5$ & $<0.5$ & $<0.1$ & $<0.2$ & 21.0 & 5.0 \\
\hline 8 & $3.0 \sim 4.5$ & $<1.3$ & $4.5 \sim 5.5$ & $<0.5$ & $<0.1$ & $<1.0$ & $<0.5$ & $<0.3$ & $<0.5$ & 24.5 & 3.0 \\
\hline 9 & $3.0 \sim 4.5$ & $<2.0$ & $4.5 \sim 5.5$ & $<0.5$ & $<0.1$ & $<1.0$ & $<0.5$ & $<0.3$ & $<0.5$ & 26.6 & 2.5 \\
\hline 10 & $3.0 \sim 4.5$ & $<1.3$ & $7.5 \sim 9.5$ & $<0.5$ & $<0.1$ & $<1.0$ & $<0.5$ & $<0.3$ & $<0.5$ & 28.8 & 3.0 \\
\hline 11 & $3.0 \sim 4.5$ & $<2.0$ & $7.5 \sim 9.5$ & $<0.5$ & $<0.1$ & $<1.0$ & $<0.5$ & $<0.3$ & $<0.5$ & 30.1 & 2.0 \\
\hline 12 & $0.5 \sim 1.5$ & $<2.0$ & $7.5 \sim 9.5$ & $<0.5$ & $<0.1$ & $<1.0$ & $<0.5$ & $<0.3$ & $<0.5$ & - & - \\
\hline
\end{tabular}


ち第 1 種及び 2 種は $\mathrm{Al}-12 \mathrm{Si}$ 系、第 3 種及び第 4 種は $\mathrm{Al}-9.5 \mathrm{Si}-0.5 \mathrm{Mg}$ 系、第 7 種は $\mathrm{Al}-5 \mathrm{Si}$ 系、第 8 種及び 9 種は Al- $5 \mathrm{Si}-4 \mathrm{Cu}$ 系、第10種及び11種は Al-8.5 Si-4 $\mathrm{Cu}$ 、第12種は $\mathrm{Al}-8.5 \mathrm{Si}-1 \mathrm{Cu}$ 系である。従つて此処で は Al-Si 系を中心として、Table. 1 に示した硬い金属 間化合物が合金熔湯中に発達する可能性を先ず考察する こととする。

\section{a. 金属的ハードスポツト発生の条件}

極く純粋なアルミニウムと硅素を配合した合金であれ ば、 $\mathrm{Si}$ 含有量 $11.7 \%$ に達する迄は硅素は初晶出せず、 共晶として晶出する。従つてダイ鋳物の場合のように急 冷される時は、共晶硅素は微細に晶出するから、ハード スポツトの原因とはなり得ない。津村氏 ${ }^{3)}$ によと、 $\mathrm{Si}$ 6 10\%合金が金型中で急冷される場合には、ナトリウ ムによる改良処理を施さなくとも、合金中に晶出する硅 素粒子の大きさは大半が 300 メッシュ $(0.05 \mathrm{~mm})$ 以下 である。

硅素含有量が共晶点 (11.7\%) を越えると、硅素が初 晶出する範囲に入るから、条件によつては、硅素の初晶 が熔湯中で大きく成長する機会があり得る。その条件と いうのは共晶温度 $\left(577^{\circ} \mathrm{C}\right)$ に極めて接近した低温に熔 湯を長時間保持することであり、わが国のプラクテイス のように、半熔融状態の湯を鋳込む方法では、ハードス ポツト発生の危険を生ずることとなる。Photo. 1. c は $\mathrm{Al}-20 \% \mathrm{Si}$ 合金中で成長した初晶硅素の実物写真であ る。

硅素結晶の比重は、Table.1に示したように2.4で、 アルミニウム熔湯 $(2.6 \sim 2.7)$ よりも軽い。従つて一度 硅素が熔湯中に初晶出すると、時間と共に偏析を起して 熔湯の上部に浮ぶ傾向があり、このために熔湯の上部は 平均として硅素含有量が高まる結果となる。ダイ鋳物の 操業では、熔解鍋の湯を少量宛上部から順次に汲み取つ て鋳込むために、熔湯中に初晶出し、湯の上部に偏析し た硅素の初晶を汲みとる機会が多くなる。

アルミニウムダイ鋳物合金第 1 種抢よび第2種(Table. 2 参照）の硅素含有量は11～13\%と規定されているから この合金を使用する場合には、熔解鍋の温度を時々上げ て擋挷し、偏析浮上している初晶硅素を熔かし込む操作 が必要である。

極く純粋な $\mathrm{Al}-\mathrm{Si}$ 合金であると、硅素の初晶出する成 分範囲は前述のように11.7\%であるが、実際の合金には Table. 2 に示されているように、銅、鉄、マンガン、マ グネシウム、覀鉛等の他に、微量でも共晶点の位置に大 きな影響を与えるナトリウム、カルシウム、等が含まれ る。これ等の元素が単独でシルミンに添加された場合の 共晶点の位置等は、金相学的には既に明かにされている が4)実際の合金には上記数種の元素が複合の影響を与え
ることになるから簡単でない。各種元素含有の程度によ つては、Si 10〜11\%程度でも硅素が初晶出する成分範 囲に入ることもあり得るし、ある元素の量が増えれば、 Table. 1 に示したような別種の金属間化合物が初晶出す る範囲に入ることともなる。以下簡単にこれ等第三元素 の影響を記すこととする。

鉄 Al-Si 合金に鉄が入ると Table.1に示したような $\mathrm{Al}-\mathrm{Si}-\mathrm{Fe}$ 系の三元化合物が初晶出するようになる。

(Photo. 1. e および $\mathrm{f}$ 参照) これらの化合物はいずれ も硬いから、大きく発達すれば当然ハードスポットにな る。なおこれらの化合物が初晶出する合金の成分範囲は Table. 1 に示してある。硅素含有量の高い合金程比較的 少量の鉄が入つても三元化合物によるハードスポツト発 生の危険性を生ずる事になるから注意を要する。表示の ように、凡ての硅素含有量を通じて絶体安全な鉄の含有 量は0.8\%であるから、Table. 2 に示されている JIS 規 格案の鉄許容量の範囲内でも、ハードスポツト発生の危 険性がないとはいえない。もつとも硅素含有量の低い合 金では、鉄は凡そ $1.5 \%$ 程度まで入つても安全である。

上記三元化合物を生ずる成分範团の合金でも、熔湯の 温度を高くしておけば、無論化合物は晶出しない。熔湯 の温度が㠜固点 (固相線の温度) に近いギリギリの低温 である場合にだけ、大きく晶出する可能性が起るわけで ある。

又これらの鉄を含む化合物は、Table. 1 に示されてい るように、アルミニウム熔湯よりも比重が大きいから、 熔解鍋の底部に偏析沈降する傾向がある。従つてよく鎮 静させたのち熔湯の擋抖をさけて上澄湯のみを使用すれ ば、ハードスポツトは発生しない。鍋の底湯を使用する 事は危険である。

銅 ダイ鋳物用合金には、Table.2に示したように、 $\mathrm{Al}-\mathrm{Si}-\mathrm{Cu}$ 系に属するものが多い。銅は $\mathrm{Al}-\mathrm{Si}$ 系の共晶 点を幾分アルミニウム側に寄せる作用がある。換言すれ ば硅素の初晶を出やすくする傾向があるが、銅を含むダ 1鋳物用合金の硅素含有量は、Table. 2 に見るように、 いずれもかなり低いから、初晶硅素がこれらの合金の八 一ドスポツトとなる危険性は比較的少い。この場合にも 鉄の増加に原因する金属間化合物の成長の方が問題であ る。鉄が加わる為にできる初晶化合物は、この場合にも $\beta(\mathrm{FeSi})$ と $\alpha(\mathrm{FeSi})$ である。（更に冷却が進めば $\mathrm{Al}$ $\mathrm{Cu}-\mathrm{Fe}$ 系のいわゆるN化合物が包晶するが、この事は ハードスポツトとは直接関係がないから省略する。方ここ れらの化合物が初晶出する成分範囲は、銅を含むに従つ ていずれも鉄の多い方にずれる。やや定量的にいえば、 これらの金属間化合物が初晶出し始める鉄の限界は凡之 1 2\%以上となる4)。こういうと銅を含む事によつて ハードスポット発生の危険性が減少するように聞えるが 
無論鉄が多ければ問題である。筆者の調べた $\mathrm{Al}-\mathrm{Si}-\mathrm{Cu}$ 系合金のダイ鋳物中で、金属間化合物によるハードスポ ツトを生じた不良品の分析例を示せば、Table. 3 のよう になる。最下欄の一例を除き鉄の含有量はいずれも $2 \%$ 以上すなわち、規格外である。な撮下欄の合金にはマ ンガンがかなり高いから、これがハードスポツト発生の 原因となつているものと思われる。

Table. 3 Results of Chemical Analyses of DieGastings in Which the Existence of Metallic Hard Spots have been Detected.

\begin{tabular}{|c|c|c|c|c|c|c|c|}
\hline \multirow{2}{*}{$\begin{array}{l}\text { Sorts of } \\
\text { die-castings }\end{array}$} & \multicolumn{7}{|c|}{ Analysed composition } \\
\hline & $\mathrm{Fe}$ & $\mathrm{Si}$ & $\mathrm{Mn}$ & $\mathrm{Cu}$ & $\mathrm{Mg}$ & $\mathrm{Zn}$ & $\mathrm{Al}$ \\
\hline Camera-body & 2.25 & 10. 2 & 0.2 & 2. 12 & 0.18 & 0.12 & bal. \\
\hline " & 2. 32 & 9.7 & 0.28 & 2.25 & 0.19 & 0.16 & "I \\
\hline " & 2.18 & 9.8 & 70.26 & 2. 13 & 0.16 & 0.08 & "I \\
\hline Camera-body I & 2.35 & 8.5 & 50.18 & 2. 57 & 0.09 & 0.15 & "I \\
\hline " & 2.18 & 7.4 & 0.35 & 3.06 & 0.21 & 0.11 & "I \\
\hline Oil-piston & 2.45 & 7.2 & 0.25 & 1.26 & 0.12 & $\operatorname{tr}$ & " \\
\hline " & 1.65 & 7.5 & 0.52 & 3. 21 & 0.18 & 0.09 & " \\
\hline
\end{tabular}

マンガン Al-Si 系にマンガンだけが単独に加わる場 合には、1\%程度までは安全であるが、同時に鉄が加わ ると、 $0.7 \%$ 程度でも硬い金属間化合物が初晶出する範 用に入る。Table. 1 に示したように、マンガンは $\mathrm{FeAl}_{3}$ 中に固溶するだけでなく、 $\mathrm{Al}_{6} \mathrm{Mn}$ 中にも固溶する。又 $\mathrm{Al}-\mathrm{Mn}-\mathrm{Fe}-\mathrm{Si}$ の四元化合物をも形成する。換言すれば 含鉄金属間化合物の量を増すばかりでなく、その晶出を 助長する作用があると考えてよい。凡そのめやすとして は、 $\mathrm{Fe}+\mathrm{Mn}$ の含量が $2 \%$ 越えないようにする事が必 要である。

マグネシウム マグネシウムは $\mathrm{Al}-\mathrm{Fe}$ 系共晶点の位 置をAl側に寄せる作用がある。いいかえるとマグネシウ ムの増加により含鉄金属間化合物が初晶出し易くなるわ けである。しかしながら、硅素と共存するとマグネシウ ムは $\mathrm{Mg}_{2} \mathrm{Si}$ なる化合物となるから、前述の作用は減少 する。

覀鈶 金属的ハードスポツトの出現には著しい影響を 与えない。

ナトリゥム $\mathrm{Al}-\mathrm{Si}$ 系合金の組織を改良する目的で加 える事がある。ナトリウムは確かに $\mathrm{Al}-\mathrm{Si}$ 系合金の共晶 組織を著しく微細化する効果はあるが、過共晶組成の合 金すなわち、硅素が初晶出するような合金の場合には、 決して初晶硅素を微細化する効果はない。むしろこれを 球状化して大きく発達させる作用があるから注意を要す る。(Photo. 1. d参照)

\section{b. 金属的ハードスポツトの防止方法}

金属的ハードスポツト発生の原因は、前項でのべたよ
うに、根本的には合金の成分の問題である。すなわち合 金の成分が Table. 1 に示したような金属間化合物を初 晶出しない組成範囲内にあれば、他の条件の如何にかか わらずハードスポツトの発生は起り得ない。実際上の問 題としては不純物、殊に鉄およびマンガンの量を合金中 の硅素含有量とにらみ合せて適当におさえておく事であ る。もつとも硅素含有量の高い合金 (Table. 2 第 1 種お よび第 2 種）の場合には、条件によつては硅素の初晶も またハードスポツトとなりうるけれども、前項でのべた 諸点に注意し、熔解方法に気をつければ避けられる。

次に合金の成分が金属間化合物を初晶出するような組 成のものであれば、必ずハードスポツトができるかとい うと、必ずしもそうでない事は前報1でのべた。この事 は熔解並びに鋳造方法と関係がある事を示している。

上記金属間化合物は、一般に低い温度では熔湯中に晶 出するけれども、温度を上げれば熔湯中にとけ込んで消 滅する。換言すれば熔湯を適当な温度まで高めておけば 均一な一液相となるから、この湯を鋳込めば硬い化合物 が大きく発達する機会はない。従つて米国のように、比 較的高温の湯を鋳込むプラクテイスを行つている所では 金属間化合物に基くハードスポット発生の問題が起る事 は稀である。これに反してわが国で行われているような 欧州式の方法、すなわち湯温を下げて半熔融状態の湯を 鋳込む方法では、しばしば問題が起るわけである。

こういうとダイカスト法としては必ず高温の湯を鋳込 まねばならないようにも聞えるが、ここではハードスポ ツト、殊にその内の金属的ハードスポツトについてだけ 論じているわけであるから、その点を抗ことわりしてお く。鋳物の収縮、ガスの問題、熔湯と炉材との反応、 (引いては非金属的ハードスポットの問題)、ダイ鋳物 機械およびダイスの耐久度の問題等をも合せて考劣れば 上記両種の方法にはそれぞれ一長一短がある事勿論であ る。

次に比較的低温の湯を鋳込む場合でも、熔解鍋の温度 を時々高めて、晶出している金属間化合物を溶入させる 操作を行うとハードスポツト発生の危険はかなりに避け られる。

金属間化合物の此重は、Table. 1 に示しょうに、初晶 硅素を除きいずれてアルミニウム熔湯よりも大きい。従 つて熔湯を鎮静させることによつて、これらの化合物を 鍋の底部に偏析、沈降させる事ができる。すなわち、熔 湯の鎮静もまたハードスポツト混入防止の一対策であ る。

以上を要約すると金属的ハードスポツト防止対策とし ては次の諸項が挙げられる。

1. 合金成分の吟味が最も大切で、不純物量を適当に おさえ、これが増量を極力さける事。 
2. 熔湯の温度を高めて、均一な一液相の湯を鋳込む ようにすること。

3. 比較的低温の湯を鋳込む場合でも、時々熔湯の温 度を高めて金属間化合物を溶入させること。

4. 熔湯のいたずらな擋找を避け、充分鎮静させる事

\section{3. 非金属的ハードスポツト}

非金属的ハードスポツトの本性、すなわち組成、発生 原因、混入の径路等は、前節でのべた金属的ハードスポ ットの場合程明膫でない。しかしながら、非金属的ハー ドスポツトは各種の金属酸化物、窒化物、炭化物、或い はそれらの複化合物で、二種の鉱㴖 (スラッグ) のよう なものと考えられる。従つてたとえこのものを抽出分離 し得ても化学分析等でその組成を決定することは甚だ困 難である。

M. Bardot, G. Duport $\left.{ }^{5}\right)$ は「軽合金鋳物中のハードス ポツトの形状、組成、原因、救済方法」なる論文中で、 コランダム $\left(\alpha-\mathrm{Al}_{2} \mathrm{O}_{3}\right)$ スピネル $\left(\mathrm{Al}_{2} \mathrm{O}_{3} \cdot \mathrm{MgO}\right)$ 稀に 石英 $\left(\mathrm{SiO}_{2}\right)$ がハードスポツトを形成するとのべてい る。このうち石英については、耐火䗲瓦、砂その他異物 の “飛び込み”ではないかと考えられるが、コランダム スピネルがハードスポツトとなり得る事は、後述するよ うに、熔湯と炉材、その他に含まれる他の 金属酸化物 (アルミニウムよりも電気化学的に貴な金属の酸化物) とのいわゆるアルミのテルミット反応によつて容易に形 成される事から当然であると思われる。

筆者( ${ }^{6}$ はこの種非金属的ハードスポツト以外に原材料 特に粗硅素から混入する非金属的ハードスポツトがある 事実を確認した。従つて非金属的ハードスポツトとして は、1. 熔湯と炉材等とのアルミのテルミット反応によ つて生ずるもの。

2. 原材料からそのまま混入するものの二種がある と考える。

\section{a. 熔湯と炉村等との反応によつて生ずる非金属的八 ードスポツト}

アルミニウムを熔解すれば、熔湯の表面にはアルミナ の皮膜ができる。この膜はアルミニウム熔湯の表面を包 み、それ以上の酸化を防ぐに役立つばかりでなく、水素 その他のガス吸収をも防止する役目を果す事はよく知ら れている。このアルミナは $\gamma-\mathrm{Al}_{2} \mathrm{O}_{3}$ と呼ばれるもので 面心立方晶 $(\mathrm{a}=7.91 \AA \AA A)$ に属し、強靮且つ緻密なため に細粒となつて熔湯中に懸垂する事は殆んどない。換言 すればハードスポツトの直接の原因とはなり得ない。

しかるに炉材その他にアルミニウムよりも貴な金属酸 化物例えば酸化鉄などがあると、熔湯はこれと激しく反 応して多量の発熱を生じ、アルミナができる。すなわち $2 \mathrm{Al}+\mathrm{Fe}_{2} \mathrm{O}_{3}=\mathrm{Al}_{2} \mathrm{O}_{3}+2 \mathrm{Fe}+188 \mathrm{kcal} / \mathrm{kg}$
これがいわゆるアルミのテルミット反応で、多量の発熱 のために反応部分の温度は瞬間的に急激に高まり、（む しこの反応を単独に行わせると還元鉄の温度は $2000^{\circ}$ 以 上にも達する）この反応によつて生ずるアルミナは $\gamma$ 型 ではなく、極めて硬い $\alpha$ 型となる。 $\alpha-\mathrm{Al}_{2} \mathrm{O}_{3}$ はもつとも 安定なアルミナで、天然には鋼玉（コランダム）、紅玉 (ルビー）サフアイア等として知られ、単斜晶形に属し ている。

Table. 4 Some Properties of Non-metallic Hard Constituents.

\begin{tabular}{l|l|l|c}
\hline $\begin{array}{l}\text { Name of the } \\
\text { constituents }\end{array}$ & $\begin{array}{l}\text { Molecular } \\
\text { formula }\end{array}$ & Hardness & Sp.gr. \\
\hline Corundum & $2-\mathrm{Al}_{2} \mathrm{O}_{3}$ & $2,500 \sim 3,000$ & 3.9 \\
Spinnel & $\mathrm{Al}_{2} \mathrm{O}_{3} \cdot \mathrm{MgO}$ & 8 mohs & $3.5 \sim 4.1$ \\
Silica & $\mathrm{SiO}_{2}$ & 1,250 & $2.6 \sim 2.7$ \\
Silicate & $\begin{array}{l}\left(\mathrm{Al}_{2} \mathrm{O}_{3}\right)_{x}(\mathrm{CaO})_{y} \\
\left(\mathrm{SiO}_{2}\right)_{z}\end{array}$ & 7.5 mohs & $3.6 \sim 3.8$ \\
$\begin{array}{l}\text { Silicon } \\
\text { carbide }\end{array}$ & $\mathrm{SiC}^{2}$ & 3,500 & 3.2 \\
\hline
\end{tabular}

その性質は Table. 4 に示したように、極めて硬いか ら、これが熔湯中に懸垂すれば、当然ハードスポツトの 原因になり得るわけである。この場合熔湯がマグネシウ ムを含めば、マグネシウムはアルミニウムよりも更に活 性であるから、上記の反応は助長され、その結果スピネ ル $\left(\mathrm{Al}_{2} \mathrm{O}_{3} \cdot \mathrm{MgO}\right)$ を生ずることとなる。

いずれにしても、上記の非金属的ハードスポツトは炉 材等との反応によつてできるものであるから、熔湯と反 応しないような炉材を選ぶ事によつて問題は解決する。 高純度のグラフアイト坩堝ならば理想的である。普通市 販のグラフアイト坩堝には多量の耐火粘土が含まれてお り、耐火粘土中には酸化鉄を含むものがあるから注意を 要する。又鉄坩城を使用する場合の塗装材料にも、不純 物を含まない上質のアルミナを使用する事が大切であ る。湿気の存在は上記の反応を助長するから、湿気の除 去と坩佩の清掃もまた重要な防止対策である。

熔解操作としてはこの種ハードスポツトに対しては熔 湯のいたずらな過熱を避ける必要がある。高温度程上記 の反応は活発となるからである。Table. 4 に示したよう に、この種酸化物の比重はアルミニウム熔湯よりも大き い。従つて前節でのべた金属的ハードスポツトの場合と 同様に、熔湯を鎮静させる事によつてこの種酸化物を坩 佩の底部に沈降させて分離する事ができる。

\section{b. 原材料からの非金属的ハードスポツト}

ダイ鋳物用アルミニウム合金の原材料としてはアルミ ニウムの他に合金元素として配合する硅素、銅、マグネ シウム等がある。このうちアルミニウム、銅、マグネシ ウム等の地金は純度も99.5\% 99.9\%程度で高く、又非 


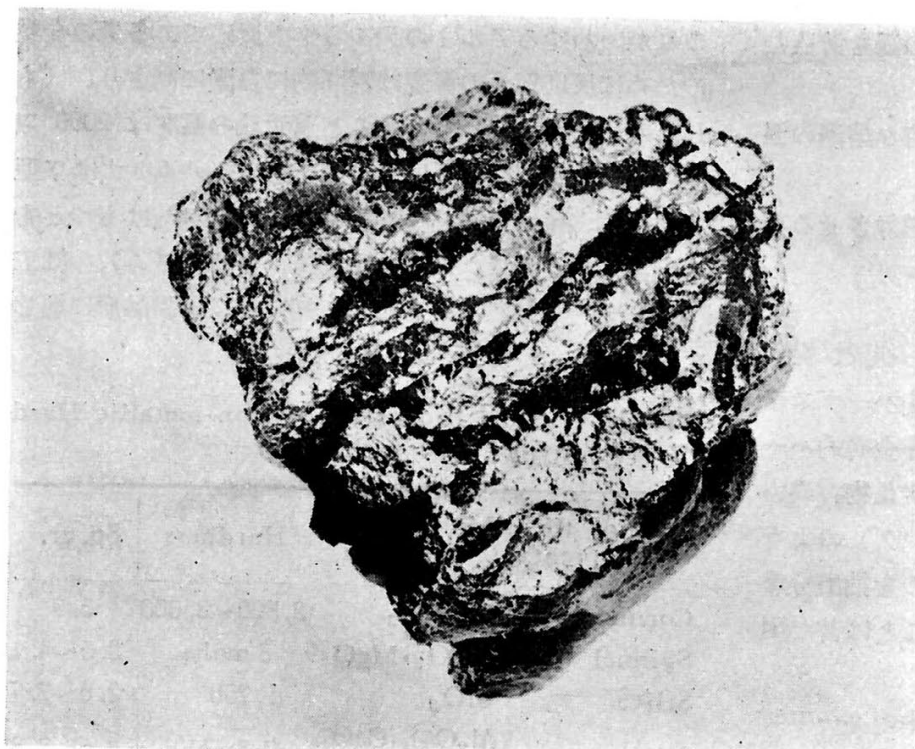

Photo. 2 Crude Silicon, Showing the Contamination of Nonmetallic Inclusions. $\times 1 / 2$

金属的介在物の如きも、仮に存在しても、極めて微量で あるから問題でない。しかし硅素は問題である。

市販の硅采は硅石を電気炉に入れて炭类で還元したた けのものであるから、その純度は96〜98\% 程度で、 Table. 5 に示したような各種の不純物を含んでいる。

Table. 5 Mețallic Impurities Contained in Crude Silicon (\%)

\begin{tabular}{c|c|c|c|c|c}
\hline $\mathrm{Al}$ & $\mathrm{Fe}$ & $\mathrm{Ca}$ & $\mathrm{G}$ & $\mathrm{Ti}$ & $\mathrm{P}$ \\
0.29 & 0.31 & 0.29 & 0.093 & 0.026 & 0.012 \\
\hline
\end{tabular}

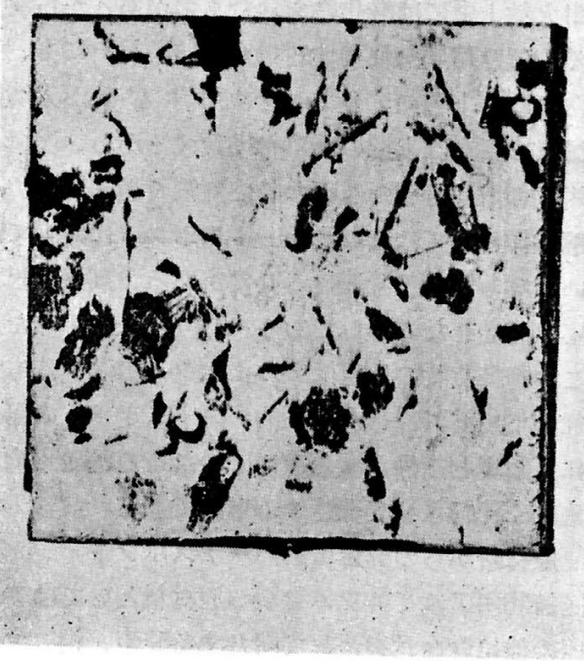

Photo. 3 Non-metallic Contaminations of Crude Silicon Found at the Bottom of the Ingot of
Al-Si Mother-alloys.
これらの不純物中特にカルシウム7)と 燐8)はシルミンになつた場合に微量でも 硅系結晶の形態に著しい影響を与える事 が知られているが、ハートスポツトとは 直接の関係はないようであるハードスポ ットの問題に対して重要なのは粗硅素中 に介在する鉱滓 (スラッグ) である。

Photo. 2 には比較的多量のスラッグを 介在する粗硅素の実物写真を示した。こ の介在物はガラス状の光沢を持ち、色は 褐色から黒色或いは青みを带びたもの等 種々である。この部分を分離して分析す ると、硅素、アルミニウム、カルシウム の他に微量の鉄、マグネシウム等が検出 される。これ等の金属元素の凡てが酸化 物であると仮定すると、Table. 6 に示し たように、100\%を越えるから、この仮 定は正しくない。酸化物の他に硅化物、 炭化物等も含まれるからであろう。

Table. 6 Composition of Non-metallic Inclusion of Crude Silicon

\begin{tabular}{c|c|c|c|c|c}
\hline $\mathrm{SiO}_{2}$ & $\mathrm{Al}_{2} \mathrm{O}_{3}$ & $\mathrm{FeO}$ & $\mathrm{CaO}$ & $\mathrm{MgO}$ & Total \\
\hline$\sim 70$ & $\sim 14$ & $\sim 0.1$ & $\sim 25$ & $\sim 1.5$ & $\sim 110$ \\
\hline
\end{tabular}

中本氏等 ${ }^{9}$ は硅化石灰製造の場合の鉱湳の組成を研究 し、鉱㵏中には10～20\%の炭化硅素（SiC）を含むこと を明らかにしている。硅素還元の場合とは無論異るであ ろうが、硅素鉱㴖中にもこの種炭化物が含まれる事が推 定される。 
いずれにしても、この種鉱滓を含む粗 硅素をアルミニウム中に合金させる場合 には、鉱涻の分離に注意しなければなら ない。炭化硅素その他造㴖酸化物の硬度 は、Table. 4 に示したように極めて高い から、この種鉣㴖の分離が不完全であれ ば、当然ハードスポツトを形成する事に なる。

Photo. 3 には硅系13\%を含む $\mathrm{Al}-\mathrm{Si}$ 母合金の $10 \mathrm{~kg}$ インゴツトの瓦部に見出さ れた粗硅素中の介在物と全く同一物の存 在を示し、Photo. 4 にはこの母合金を使 用して作られた夕゙イ鋳物(計算器の部品) 中の同一介在物（ハードスポツト）の仿 在在示す。

この種原材料から来る非金属的ハート スポツトの防止方法レしては、無諭原材 料の吟味が最も重要であるが、母合金等 の熔解操作に留意する事によつて避けら

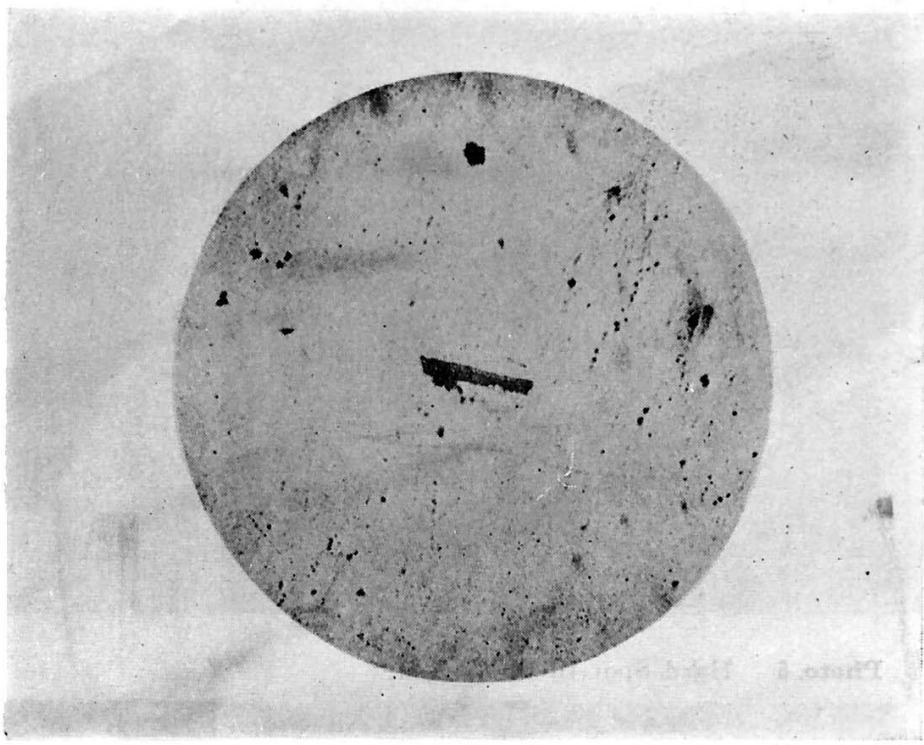

Photo. 4 Same as Photo. 3, Detected in Some Product of Diecasting.
れる。例えばシルミン母合金製造の場合には、揢湯の温 度 $900^{\circ}$ 附近まで加熱し、鉱㴖の分離を訃つたのち、峉湯

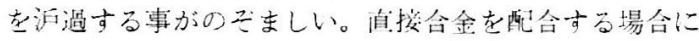

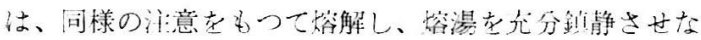
ければならない。

\section{4. ダイ鋳物（写真機部品）中に見出されたハ ードスポツトの実例}

Photo. 5, a, b およびcは、ダイ鋳物委員会が写貞機業 界から提供をうけたハードスポツトの保在による仕上不 能と称せられるカメラ部品ダイ鋳物製品の実物挲·真です る。いずれの部品にも、墨で囲つた矢印の部分にはハー ト゚スポツトが検出される。殊に Photo. 5. c には、側面 写真に見られるように、工具が平滑に切削せず凹凹を生 じ、凹の部分にはそれぞれ大きなハードスポットが見出 される。

Table. 7には供武ダイ鋳物の分析結果を示す。Photo. 5. a の実体は従来のラウタルに近く、Photo. 5.bは試料
不足のため分析は行えなからたが、組織からみて a，の 組成に近い。Photo. 5. c は高硅素ラウタルである。

Table. 7 Composition of the Al Alloys Shown in Photo. 5.

\begin{tabular}{ll|l|l|l|l}
\hline & $\mathrm{Cu}$ & $\mathrm{Mg}$ & $\mathrm{Mn}$ & $\mathrm{Fe}$ & \multicolumn{1}{|c}{$\mathrm{Si}$} \\
\hline Photo. 5. a & 2.40 & 0.022 & 0.016 & 0.96 & 4.42 \\
Photo. 5. c & 1.80 & 0.22 & 0.16 & 0.76 & 8.74 \\
\hline
\end{tabular}

Photo. 6. a および b は、Photo. 5. a の矩印の部分に 見出されたハードスポツトである。この介在物はかなり に大きく $1 〜 2 \mathrm{~mm}$ に達し、ミフ 硨度測定の結果は次 のようであつた。

黑褐色の部分 …383, 385, D.P.H.

幾分白味を帯びた部分…...572，514，572，D. P. H.

検鏡の結果によると、このハードスポツトは明らかに 非金属的のもので、Photo. 3. b に示した粗硅素中の鉱㴖 的な介在物と酷似しているから、打そらく粗硅素に原因 するものと思われる。合金の組織は Photo. 6. b に見る

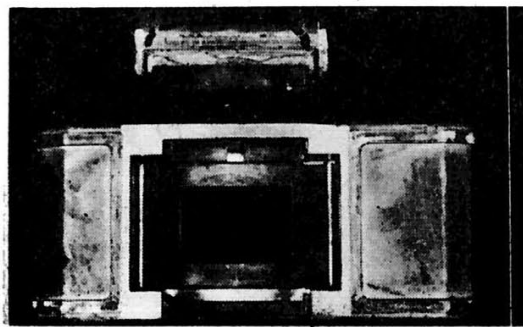

a

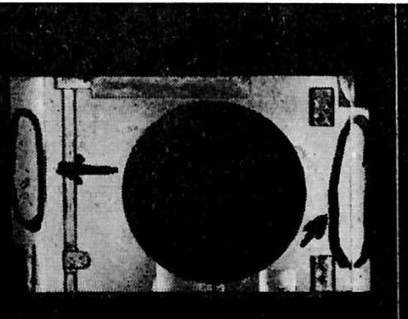

b

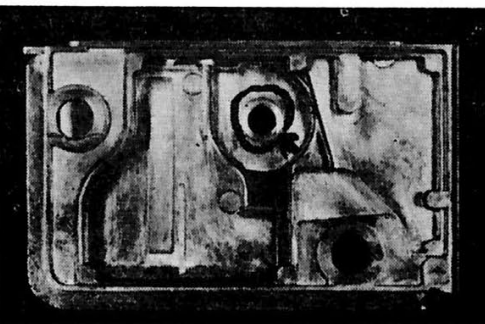

c

Photo. 5 Showing the Position of Hard Spots Detected in the Camera-bodies, the Products of Die-casting. (The positions are shown with arrows. ) 


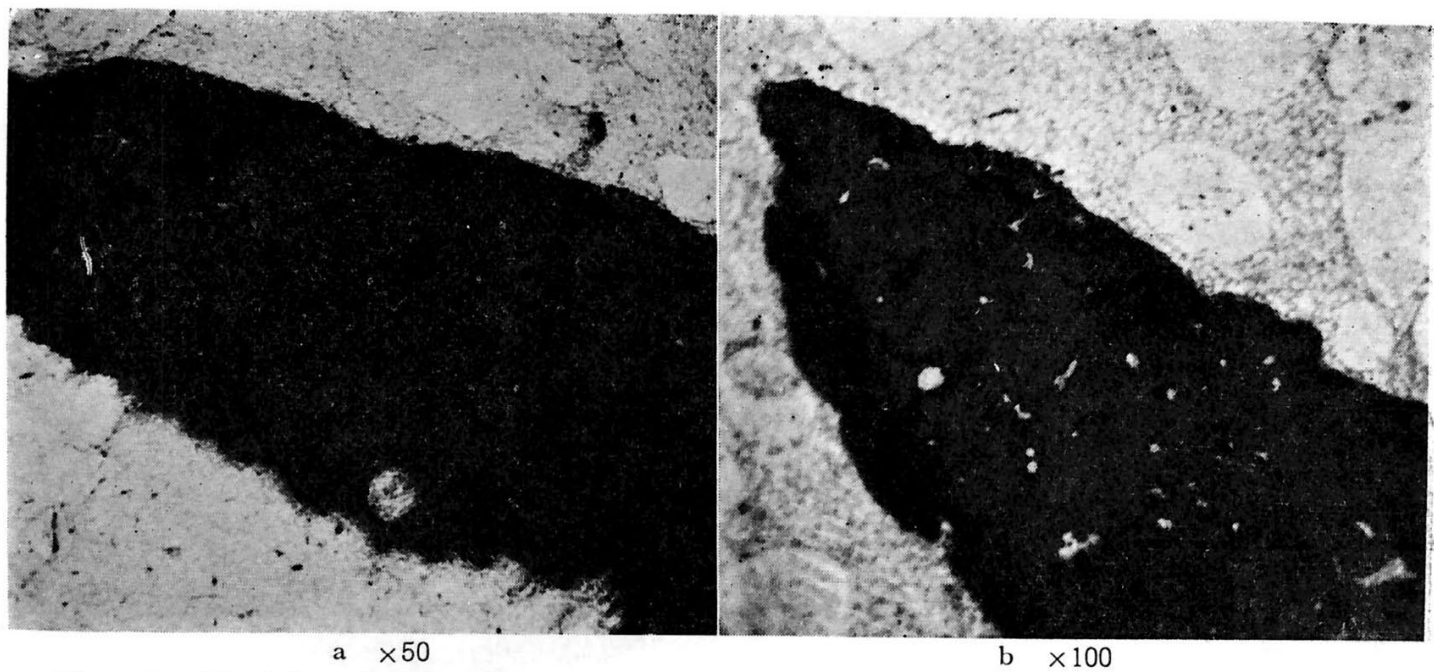

Photo. 6 Hard Spot in Photo. 5, a.

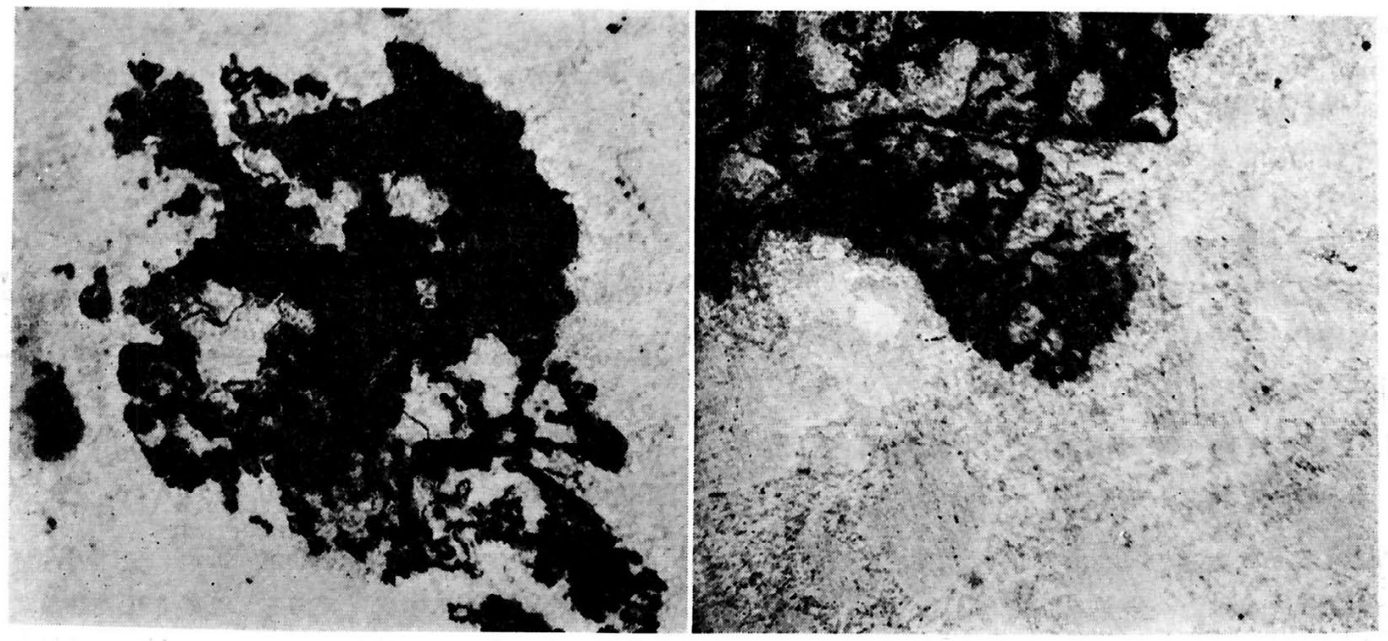

Photo. 7 Hard Spots in Photo. 5.6.

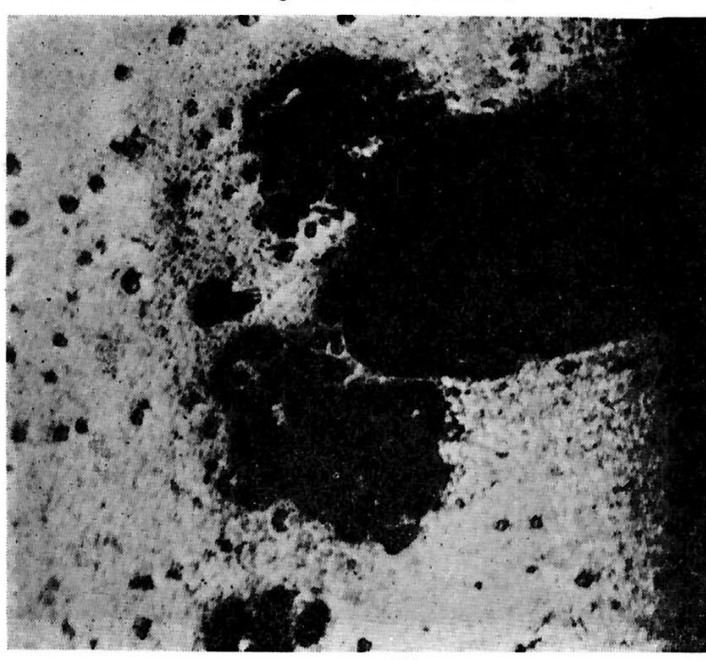

b $\times 100$

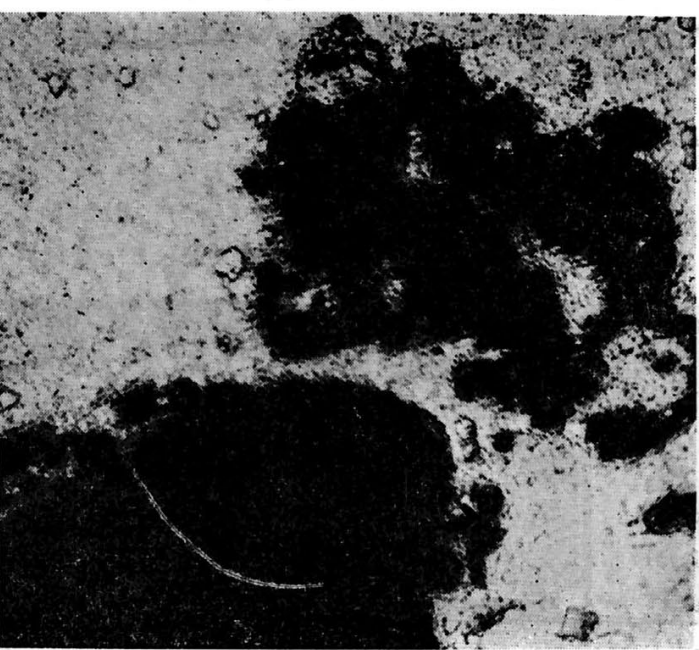

Photo. 8 Hard Spots in Photo. 5. c.

b $\times 100$ 
ように、 $0.1 \mathrm{~mm}$ 位の大きさのアルミニウムの初晶の周 囲に微細な共晶がある。恐らく注湯時の熔湯の温度はア ルミニウムが初晶する位の低温で、いわゆる半熔融合金 を鋳込んだものと思われる。

Photo. 7 a および b は、Photo. 5. b 中に見出された 八ードスポツトである。これも明らかに非金属的のもの であるが、Photo. 6 とは若干相違する。大きさは $0.8 \times$ $0.9 \mathrm{~mm}$ 程度で、色は黒褐色である。割れ目が多いので 確かな硬度数を示し難いが、部分により 150〜322D. P.

H. の程度である。Photo. 6 中のハードスポツトより幾 分軟い。混入の径路等は従つて不明であるが、酸化物を 主体とするものと思われる。

Photo. 8. a 及び b は、Photo. 5. c に見出されたハー ドスポツトである。大きさはやはり $1 \mathrm{~mm}$ 前後で、塊状 の部分は光沢並びに色共に、Photo. 6 に示したものと類 似する。従つて硬度も高く、粗硅素中から混入した非金 属的介在物であるとも思われる。

以上を総括するに供試ダイ鋳物中のハードスポツトは いずれも非金属的のものばかりであるが、その混入の径 路は必ずしも明膫でない。しかしながら、粗硅素中の介 在物に比較的類似のものが多いから、シルミン母合金の 製造に注意し、合金配合の際にもこの点に気をつければ この種のハードスポツトの大半は避け得られるものと思 われる。

\section{5. 結言}

ダイ鋳物にあらわれるハードスポツトには、大別して 金属的なものと非金属的なものとがある。金属的なハー ドスポットの種類としては、Table. 1. 及び Photo. 1 に 示した各種の硬い金属間化合物がある。非金属的なハー ドスポツトとしては、熔湯と炉材等とのアルミテルミッ ト反応によつてできるコランダム、スピネル等を主 体とするものと、原材料殊に粗硅素に含まれる鉱掻的介 在物の二種がある事を示した。従つてハードスポツトの 防止対策としては、おの打のの原因に対してそれぞれ異 る注意が必要となつて来る。すなわち各種の原因に対す るハードスポツト防止対策としては次の諸項が举げられ る。

I 金属的ハードスポツト

a. 合金成分の吟味

1. 不純物特に鉄及びマンガンの許容量の低下。

2. 規格外不純物ナトリウム、燐、カルシウム等の 影響 b. 熔解操作上の注意

1. 熔湯温度の上昇

2. 熔湯の鎮静

II 炉材との反応によつてできる非金属的ハードスポ ット

a. 炉材の吟味

1. グラフアイト坩堝の質、殊に含有耐火粘土の検 討。

2. 湿気の除去と坩堝の清掃

3. 鉄畦佩の塗装材料の検討

b. 熔解操作上の注意

1. 熔湯の過熱防止

2. 熔湯の鎮静

III 原材料から来る非金属的ハードスポット

a. 原材料の吟味

1. 原材料附着不純物の除去

2. $\mathrm{Al}-\mathrm{Si}$ 母合金の検討

3. 原料硅素中の鉱滓の検討

b. 熔解操作上の注意

1. 熔解温度の上昇

2. 熔湯の洰過

3. 熔湯の鎮静

終りにのぞみ、この研究遂行に協力されたダイ鋳物委 員会、写真機製造業者組合の各位に謝意を表すると共に ハードスポツトの検出に努力された小松助教授、寺沢助 手、写真撮影に協力された板橋親治氏に深く感謝の意を 表し、種々なる助言をいただいた千代田金属精鍊株式会 社津村善重氏に対しても謝意を表したい。又この研究遂 行に対しては、財団法人軽金属奖学会よりの研究費の一 部が充てられた事を附記する。

\section{文献}

1）大日方一司、本誌、12 (1954) 74

2）大日方一司、小松登、日本金属学会誌、19'(55) 736,197

3）津村善重：日本金属学会誌、未発表

4) 大日方一司、小松登、日本金属学会誌、17，(195 4), A-8 121.

5) M. Bardot, G. Duport, Fondérie 38(1949), 1470

6) 大日方一司、軽金属協会1955年春期講演会で講演

7) 津村善重、本誌、17 (1955) 51

8) G. Gürtler, Z. Metallk., 44 (1953) 503

9) 中本、斉藤、豊田、水牧、鉄と鋼、41 (1955) 11 61. 